NGTT Deel 54, Nommers 3 \& 4, September en Desember 2013

Meyer, Esias E

University of Pretoria

\title{
Rituals and social capital in the book of Leviticus? An attempt at an interdisciplinary discussion
}

\begin{abstract}
The article is an attempt by an Old Testament scholar to engage with a debate taking place in practical theology. This debate is about the influence of religion and ritual on the formation of social capital. The author attempts to shed light on this debate by looking at the two halves of the book of Leviticus, the first half of which is dominated by ritual and the second half is characterised by a broader communal perspective.
\end{abstract}

\section{INTRODUCTION}

In an essay on "Ritual and the generation of social capital in contexts of poverty" Cas Wepener and Johan Cilliers (2010:417) start their search for a definition of social capital as follows:

"Social capital can be defined in numerous ways. However, in most of these definitions it is noted that the dimension of 'bonding' (the set of horizontal associations between people, consisting of social networks and associated norms) must be complemented by a vertical component of 'bridging' (ties that transcend various social divides, such as religion, ethnicity and socio-economic status) in order to prevent the horizontal ties from becoming a basis for the pursuit of narrow and even sectarian interests."

The concepts of "bonding" and "bridging" seem to be part and parcel of the idea of social capital. In his book Rein Brouwer (2009:72-118), offers an overview of the development of the concept of "social capital" and definitions of "bonding", "bridging" and also "linking". Bonding and bridging apparently go back to Robert Putman, who started using them in 1995 (Brouwer 2009:72-76). Yet the objective of the essay by Wepener and Cilliers (2010:417-419) is to explore the relationship between certain rituals (or specifically liturgies) and the formation of social capital in a context of poverty. The problem they engage with seems to be part of a broader debate (within practical theology) on the role that religion, religious organisations and churches play in the creation of social capital. ${ }^{1}$ Brouwer (2009:117) concludes that, in his view, religion does play a role in the generation of social capital and this is also what Wepener and Cilliers attempt to argue in the light of their specific case study.

Social capital is furthermore not something unique to practical theology, but as Bayat (2005:2) puts it "scholars of diverse backgrounds have researched it", especially scholars from sociology, political science and economics. In Bayat's (2005:3) attempt to define the concept of social capital he refers to definitions which include both values (like social trust) and a network established between people. Social capital is essentially "relational, not something owned by any individual but rather something shared in common." (Bayat 2005:3) Later Bayat (2005:4) provides a more specific definition of trust in which he defines trust as "the understanding that the person or member of the social group will act in a manner that is mutually beneficial..."

1 See Brouwer (2009:96-117) for an overview of the broader debate within practical theology. 
NGTT: Oopbron - http://ngtt.journals.ac.za

What Bayat's definition has in common with that offered by Wepener and Cilliers above, is a focus on the relations between people and the networks created as a result of these relations. But why study these networks in the first place? At the start of his paper Bayat (2005:2) provides us with a reason for studying social capital:

Social capital holds out the promise of improving access to resources amongst and across different groups and people. So we are interested in social capital because we consider it a new way of thinking about how resources can be mobilized and distributed (and possibly more equitably distributed) within society.

It is thus fairly obvious why subjects like economy, sociology and political science would engage with this concept. ${ }^{2}$ While it seems that within practical theology social capital is taken as a given, the main question debated is the role of ritual in the creation of social capital.

This article attempts to be part of this debate, but from the perspective of Biblical Criticism and specifically from the perspective of a particular Biblical book. The book in question is the book of Leviticus. This article is thus an attempt to generate some interdisciplinary debate. It may well be that Biblical Criticism has something to offer in a debate going on in practical theology. Alternatively, the debate in practical theology, might shed some light on the interpretation of a Biblical book. When reading the quote from Wepener and Cilliers above this author's initial response was that there is probably much more bonding going on the book of Leviticus than bridging or linking; the book of Leviticus might be a good example of the dangers of lots of bonding at the cost of bridging, but this was the initial response and, as we shall see later, there might be another side to this coin.

One obviously faces plenty of problems when setting out on this interdisciplinary road. Indeed, one enters a methodological minefield. In general, the use of social theory in the study of the Bible or ancient Israelite society is a very fruitful but highly problematic field of study in Biblical Criticism. ${ }^{3}$ To make things worse, the kind of studies in practical theology which are interested in this debate are usually based on "participating observation".4 Whereas it is possible to describe what is happening in churches today, it is impossible to do this with the Bible and the societies that produced the Bible. The societies in which and for which the book of Leviticus was written no longer exists and we have no way of going back there. As Bergen (2005:4) puts it:

"The difficulty of using modern explanations for ancient rituals is compounded by the fact that we cannot study the society in which the ritual operates. All we have is the text of the Bible as a guide to the specifics of 'Israelite society'.'

We only have texts and texts are not rituals which can be directly observed. Wright (2012:197) correctly points to the fact that:

"[I]t is clear that the written text is not a ritual as a performance. It is a written artefact that describes or, more particularly, prescribes a performance. Such a text contrasts with what most social scientists work with when they do ritual analysis. [italics in original]"

\footnotetext{
2 See also Bayat (2005:3-4) on the criticism aimed at the construct of social capital. Some of the problems include "lack of definitional clarity", "measurement issues", "huge diversity of fields" using it etc.

3 See the very recent essays in Olyan (2012).

4 See Brouwer (2009:83), who argues that a "methodology is needed which allows us to be close to the experience of people" (my translation). Or see Wepener and Cilliers (2010:421), who describe and motivate how they did their field work, or Wepener and Barnard (2010).
} 
NGTT Deel 54, Nommers 3 \& 4, September en Desember 2013

Wright (2012:198) argues that despite all these pitfalls, scholars should still attempt to apply social theory to Biblical texts, but that this should entail a fair amount of being "forthright" about the limits of our analysis. It also means that sometimes only parts of a theory might be applicable; he then concludes (Wright 2012:199):

"In these cases, extracting or modulating aspects of theoretical approaches and application to Biblical ritual texts becomes more the study of a literary motif in the text than of real-world social phenomena. [my italics]"

We are thus applying social theories developed in today's world to literary motifs in ancient texts. In the past two centuries Biblical critics have developed different methods of reading these texts. Some of these insights will be used below.

Apart from underlining the gap between our world and the Biblical world, Bergen (2005:5) also introduces us to another methodological problem, namely the problem of the definition of ritual. One is often tempted to agree with Wright $(2001: 8)$ that "one knows ritual when one sees it", ${ }^{\prime \prime}$ but this view is not really helpful. Some practical theologians ${ }^{6}$ use a very specific definition of ritual, but many Biblical critics seem to side with Catherine Bell ${ }^{7}$ for a more open definition away from "a strict or totalizing 'theory"' (Bibb 2009:53). For Wright (2001:13) Bell points out the "contrast between ritualisation and normal activity" and this is important. One should also add that Biblical Criticism has through the years tended to use terms like ritual in a very general sense. In the classical documentary hypothesis it was always argued that one of the characteristics of the Priestly source $(P)$ was its interest in "ritual observance" (Collins 2004:57) or "ritual phenomena" (Zenger 2008:158). This has to do with the fact that P focuses on the cult and the rituals needed to maintain this cult, but this has also helped the $P$ source to not find itself "in the path of the cyclone that ravaged" (Ska 2006:146) the other sources of the classical documentary hypothesis. To use Bell's concept of "ritualisation", one could argue that the fact that "ritualisation" is so prevalent in the P source helped to distinguish it from other sources. ${ }^{8}$ But first we need to engage with a fairly old problem in the interpretation history of Leviticus. After facing this problem we will explore the following question: Could the concept of "social capital" as defined in practical theology be helpful in offering some new insight into the old problem we are about to address?

\section{Ritual AND ETHICS in LeViticus}

Leviticus is clearly a book divided into two halves. The second half of the book (Lev 17-26) has traditionally been called the Holiness Code $(\mathrm{H}),{ }^{9}$ and one of the important differences in the second half is that certain ethical and moral issues are addressed, issues which were

5 See also Bergen (2005:5) for similar comments.

6 See Wepener (2010:1), who argues that "rituals are often repeated, self-evident, symbolic actions, that are always interactive and corporeal, sometimes accompanied by texts and formulas, aimed at the transfer of values in the individual or the group, and of which the form and content are always culture, context and time bound, so that the involvement in the reality which is presented in the rituals remains dynamic."

7 See Bell (1992:69-93), or see discussions by Wright (2001:8-13) and Bergen (2005:5-6). The most extensive discussion of Bell by a Biblical critic that I know of is Bibb (2009:52-69).

8 Even in current Pentateuch scholarship, after the demise of $\mathrm{J}$ and $\mathrm{E}$, one still talks of $\mathrm{P}$ and non-P, as the recent book by Carr (2011) shows.

9 The term "Holiness Code" was coined in 1877 in an essay by A. Klostermann "Ezechiel und das Heiligkeitsgesetz", later to be published in Klostermann (1893:385). 
NGTT: Oopbron - http://ngtt.journals.ac.za

not raised in Leviticus 1-16. In the days of Wellhausen it was argued that the Holiness Code (H) was an older collection which had at some stage been incorporated into Leviticus, or in Wellhausen's terms added to the "Priestercodex". ${ }^{10}$ In this scheme of things the moral issues addressed reflected something of an older religion still closely connected to agriculture (Trevaskis 2011:4).

Things have radically changed in the last few decades with more and more scholars agreeing that $\mathrm{H}$ was created later than Leviticus 1-16. There are two groups of scholars who support this view. On the one hand, there are (mostly) Jewish scholars who belong to what one could call the "Kaufman School",11 of which Jacob Milgrom and Israel Knohl would probably be the foremost examples. For both Milgrom and Knohl $\mathrm{H}$ was produced by a Holiness School that consisted of priests, but who belonged to a later generation than those who produced the bulk of the earlier Priestly source (P). In Europe similar arguments are followed by scholars belonging to the "redactional critical"12 school, of which Eckart Otto, Reinhard Achenbach and Christophe Nihan would be good examples. These two groups differ on the dating of these texts, but they agree on the chronological relationship between $\mathrm{P}$ and $\mathrm{H}$. For all of them $\mathrm{H}$ was written after $P$.

One of the arguments ${ }^{13}$ used to argue for the distinction between $\mathrm{H}$ and $\mathrm{P}$ is the fact that, whereas $\mathrm{P}$ is focused on the cult itself and the rituals aimed at maintaining the cult, $\mathrm{H}$ broadens its horizons to include what we might call "ethics". Bibb (2009:152) puts this as follows:

"The central movement [from $\mathrm{P}$ to $\mathrm{H}$ ] ... is the shift from a narrow cultic focus to the larger communal setting."

What is meant by a "narrow cultic focus" and a "larger communal setting"? Or what is meant when one describes this as a move from "rituals" to "ethics"? The answer to these questions is fairly simple and a brief overview of the content of the book of Leviticus should make this clear.

Most ${ }^{14}$ of the laws in Leviticus 1-16 are concerned with the cult and maintaining the cult. Leviticus 1-7 is about different kinds of offerings, which include the burnt offering (chapter 1), the grain offering (chapter 2), the offering of well-being (chapter 3), the purification offering (chapters 4 and 5), the reparation offering (chapter 5) and some more general instructions on sacrifices (chapters 6 and 7). Leviticus 1-7 is thus concerned with rituals which are aimed at maintaining the sacrificial cult. In terms of genre they are legal texts prescribing how certain rituals (sacrifices) should be executed. They are prescriptive and not descriptive, as Wright pointed out above. Leviticus 1-7 is followed by the first narrative in the book of Leviticus namely chapters 8-10. Chapters 8-9 describe how Aaron and his sons are ordained and this leads to the cultic climax at the end of Leviticus 9, when the glory of the Lord appears to all the people (verse 23). Eventually, fire comes from the Lord and consumes the burnt offering and the fat on the altar. The people are in awe, but then, in Leviticus 10 things take a turn for the worse, when the sons of Aaron die because they did something wrong. This narrative is thus

10 See Wellhausen's comment quoted in Otto (1999:132).

11 By the "Kaufmann School" I refer to scholars who argue that the Priestly texts are pre-exilic. See Meyer (2010).

12 As described by Jeffrey Stackert (2009:195).

13 Especially used by Milgrom (2004:215-219) and Knohl (1995:175-180).

14 The following overview of Leviticus was presented in another article. See Meyer (2013:1-2). 
NGTT Deel 54, Nommers 3 \& 4, September en Desember 2013

describing certain sacrificial rituals, of which some actually went terribly wrong. ${ }^{15}$ Few scholars would dispute that the acts prescribed and described in Leviticus 1-10 are indeed rituals, but we cannot really observe them - we can only read the texts.

Leviticus 11-15 is concerned with clean and unclean animals (chapter 11), female purification after childbirth (chapter 12) and then three chapters (13-15) on 'leprosy'16 and bodily fluids follow. Chapter 11 is about correct eating, whereas chapters 12-15 tend to describe the procedures (rituals) to be followed by somebody who has become unclean because of the conditions described and wants to become clean again. Leviticus 16 is about the Day of Atonement and it also portrays sacrifices made to bring about reconciliation between $\mathrm{YHWH}$ and his people. These texts thus clearly focus on the cult and could be described, as Bibb (2009:152) did, as having a "narrow cultic focus". Apart from Leviticus 11, it should be clear that these texts also prescribe certain rituals. Yet even if Leviticus 11 is simply a list of what is allowed to be eaten and what not, it is clearly part and parcel of the rest of the text and concepts such as pure and impure dominate. We will return to this chapter later.

In the second half of Leviticus there is a movement away from this "narrow cultic focus" to broader issues. This movement is not really evident in Leviticus 17, which is usually regarded as the first chapter of the Holiness Code. Chapter 17 forbids profane slaughter and the eating of blood. This chapter is often regarded as a kind of hinge between the preceding half of Leviticus and the subsequent Holiness Code. ${ }^{17}$ One community-related concern which now comes to the fore is the relation between the Israelite and the stranger ( $g e \bar{r}$ ). Strangers were also forbidden to carry out profane slaughter and they were not allowed to consume blood either. The strangers actually appeared for the first time in the previous chapter (Leviticus 16), where they are also forbidden to work on the seventh day of the tenth month. In the rest of the Holiness Code we find a clear communal focus in some texts, such as Leviticus 18 to 20 and also in 25. Chapters 18 and 20 are concerned with sexual taboos, but especially in an extended family context, whereas chapter 19 is a strange mix of various kinds of legal texts. Some texts are reminiscent of the more cultic texts in the first half of Leviticus interested in both sacrifices and purity issues, while others remind us of the Decalogue and still others have been described as promoting "social justice". ${ }^{18}$

It is especially the latter two categories, namely texts reminding us of the Decalogue and texts concerned with "social justice", which are described as more ethical. Balentine (1999:169) describes the laws of Leviticus 19 as "social ethics". Decalogue-like texts include Leviticus $19: 3,4,11,12,16,18$ and $29 .{ }^{19}$ Texts that are often described as addressing issues of "social justice" include especially 19:11-18, in which one finds commandments against keeping the day labourer's wages until morning, or putting a stumbling block in the way of a blind person, cursing the deaf and being partial in judgment. These laws are aimed at protecting the vulnerable in society, the kind of thing one finds in some of the Latter Prophets. One also finds laws protecting your neighbour from slander and from being hated by the addressees,

15 Bibb (2009:111) talks of "ritual failure" in Leviticus 10.

16 This term is traditionally used, but it does not refer to Hansen's disease. When found on a human being,

it is more a kind of skin disease and it can even be found in houses when it becomes a kind of mould.

17 See Meyer (2012:106-124).

18 See, for instance, Nihan (2007:461), who argues that verses 11-18 have "a strong thematic unity, since all the prohibitions deal in one sense or another with the issue of social justice."

19 The list is from Balentine (1999:169 n. 78), who took it from Kaiser (1994:1131). I am not entirely convinced that verses 18 and 29 have much to do with the Decalogue. 
NGTT: Oopbron - http://ngtt.journals.ac.za

but instead addressees are commanded to love (verses 17-18) their neighbours as themselves, an injunction made famous by Jesus (Mark 12:31). Similar commands are again found in verses 33-34, which forbid the addressees to oppress the stranger and once again the addressees are asked to love the stranger as themselves.

This is what Bibb and others are referring to, namely the fact that the first half of Leviticus focuses on the cult, while in the second half of Leviticus the focus is indeed wider and includes texts discussing the relationship between Israelites and their fellow Israelites as well their relationship with strangers. One could describe this as a kind of "turn to the other" as long as one qualifies this as not meaning a "turn away from the cult". The sanctuary and the rituals associated with maintaining it are still very much at the centre, but other broader perspectives are included. Collins (2004:151) puts it well:

"The code does not lessen the importance of ritual and purity regulations, but it puts them in perspective by alternating them with ethical commandments. Holiness is not only a matter of being separated from the nations. It also requires ethical behaviour toward one's fellow human beings."

One could illustrate the point further by looking at how the concept of holiness ${ }^{20}$ is used in the Holiness Code compared to the first half of Leviticus. In the first half the term is applied only to the cult, its officials and paraphernalia, ${ }^{21}$ but in the second half it is applied to ordinary people, $^{22}$ who are now asked to be holy themselves. Yet, it should be clear that there is a very obvious move in the second half of Leviticus away from a narrow cultic focus to a broader view of the community and the responsibility of community members to take care of each other, including strangers, the poor and other vulnerable people. One could describe that movement as a movement from ritual to ethics, and the question that has obviously kept Biblical critics busy is: why? Why does the book broaden its horizons from focusing on the cult and its rituals to include the behaviour of Israelites to one another and even to outsiders?

Before we look at how Biblical critics have engaged with this problem, one could ask whether this question should not be asked within the broader debate of the role played by religion in the creation of social capital. To put it rather crudely: Could one not argue that the kind of community created by the rituals [or ritualisation] in Leviticus 1-16 inevitably becomes a society that cares for its own members and vulnerable people in their midst? It even takes care of outsiders like the strangers just mentioned! It would be fascinating to ask what kind of effect the "ritualisation" of society described in Leviticus 1-16 had on the society itself. Is Leviticus thus a good example of how rituals and cult create social capital?

\section{ResPonse by BibliCAL CRITICS}

As we will see in a moment the short answer is: "No!" The movement in the book of Leviticus from cult to society is not an example of the creation of social capital. Let me explain: as already mentioned above, Biblical critics usually do not read the two halves of Leviticus as the product of the same society living in the same time period. We have already noted that Wellhausen initially thought that $\mathrm{H}$ was older and that the more ethical view of $\mathrm{H}$ deteriorated

20 See especially Wright (1999:351-364).

21 E.g. Leviticus 6:9-20; 8:10,11, 12, 15 and 30.

22 See Leviticus 19:2; 20:7-8. 
NGTT Deel 54, Nommers 3 \& 4, September en Desember 2013

into the more ritualistic perspective of $\mathrm{P}$ in the first half of Leviticus. ${ }^{23}$ We also mentioned that in current scholarship more and more scholars are arguing for the opposite chronological relationship, namely that $\mathrm{H}$ is later. I will briefly sum up the view of two Pentateuch scholars (already mentioned above) who offer two different arguments to account for the movement from ritual to ethics.

Israel Knohl (1995:204-215) is of the opinion that $\mathrm{H}$ was written by a generation of priests who lived after the priests who wrote the first half of Leviticus, or what he calls the Priestly Torah (PT). The earlier priests are described as esoteric and they produced the bulk of what was traditionally known as $\mathrm{P}$. These priests were active somewhere during the tenth to the eight century $B C E$. They, their writings and the way in which they ran the sanctuary were the object of prophetic critique, especially by some of the classic prophets such as Amos, Micah and Isaiah. ${ }^{24}$ But then in response to this critique, a later priestly school called the Holiness School (HS) responded by creating $\mathrm{H}$. In $\mathrm{H}$ the focus is broader than the cultic-centred PT, as we have seen above. The turn in Leviticus from ritual to ethics is thus the result of prophetic critique and the texts with more ethical content were produced by a later generation of priests. These priests were all from the same Judean background, but they succeeded each other. It is not as if the society which practised the rituals in the first half of Leviticus suddenly developed an ethical dimension. Knohl's main argument that both $\mathrm{P}$ and $\mathrm{H}$ should be pre-exilic has unfortunately been rejected ${ }^{25}$ by most Pentateuch scholars, who still follow Wellhausen's older idea that Priestly texts are exilic/post-exilic.

Another example of a scholar who has offered an explanation for this ethical turn is Eckart Otto, ${ }^{26}$ whose dating of these texts is more aligned to the traditional later dating of Priestly texts. For Otto the origins of $\mathrm{H}$ lie in the post-exilic society and it is part of the community's struggle for identity within the larger context of the Persian Empire. Initially the corpus of Judaism in this period was a Hexateuch (the Torah plus the book of Joshua) and at this stage identity was connected to the promised land. With the book of Joshua added, the promises of land in Genesis are fulfilled, promises which are left unfulfilled in our current Pentateuch. Later the book of Joshua was removed from the Hexateuch to form the Pentateuch to define identity rather in terms of living according to the Torah and not living in the land. This is where the Holiness Code comes in. When the book of Joshua was removed, these texts in the second half of Leviticus were added to the Priestly texts in the first half of Leviticus. The purpose of the Holiness Code was to consolidate and correct other older legal codes in the Pentateuch such as the Deuteronomic Code and the Covenant Code. In this model the ethical content in the second half of Leviticus is thus the result of engagements with other texts in the Pentateuch, which already had this more ethical content. It is also part of a broader movement of identity renegotiation in the Persian period in which identity was redefined as closely connected to living the Torah and not so much to land anymore.

This is a rather complicated theory of the origins of the Hexateuch/Pentateuch and although it differs a lot from Knohl's view, both hypotheses have certain characteristics in common. Both argue that the more ethical material is later than the more cultic material and the point is that the kinds of questions raised at the end of the previous section are simply foreign to the way that Biblical critics tend to read these texts. Few would read these two halves of

23 See, for instance, the discussion by Bibb (2009:146-148).

24 Knohl (1995:204-214) mentions texts such as Amos 5:25, Micah 3:9-12 and Isaiah 5:16.

25 See, for instance, the criticism by Nihan (2007:563).

26 This is a rather brief summary of an essay by Eckart Otto (2009:135-156). 
NGTT: Oopbron - http://ngtt.journals.ac.za

Leviticus as created by the same society and it is simply not possible that there is some kind of linear movement from rituals to ethics, or if you will, from rituals to social capital. At this stage one should probably conclude that Biblical critics and practical theologians belong to two different academic worlds. But there are some concepts from the social capital debate which I do find helpful in reading Leviticus.

\section{BONDING AND BRIDGING}

I would side with those scholars (i.e. Otto and Nihan) who argue that $\mathrm{P}$ and $\mathrm{H}$ are results of the exilic/post-exilic time period and would thus tend to read the book of Leviticus (both $\mathrm{P}$ and $\mathrm{H}$ ) within the context of the Persian Period. Many scholars ${ }^{27}$ have argued that the community of the Second Temple Period was fairly conscious of the boundaries between them and the rest of humanity. This is often mentioned in debates about Leviticus 11 and the rules about eating. ${ }^{28}$ For Israel, only certain animals were allowed to be eaten. If one leaves issues of the provenance of these laws aside ${ }^{29}$ the question is usually how these laws functioned in the Persian Period. Some, such as Nihan (2007:339), have argued:

\section{"As such, much more than for the legislation of Lev 12-15, the torah of Lev 11 sets apart those who practice it from the rest of humanity." [italics in original]}

Right eating was thus not an innocent act, but something which helped to draw boundaries between Israel and the rest of humanity. Milgrom (1991:726) 30 also hints at this when he discusses the reasons why Christianity abolished the dietary laws of Leviticus 11. It was not only in order to "ease the process of converting the gentiles", but it was also about abolishing criteria which set Israel "apart from the nations". The early church thus abolished the boundaries which kept Jew and gentile apart. Could the laws of Leviticus 11 not be regarded as a kind of ritualised eating ${ }^{31}$ which demarcated the boundaries between Israel and the rest and, in terms of social capital, amounts to a case of bonding? Thus we do find some kind of social capital.

Wepener (2010:1) defines bonding as "the ways in which groups or individuals bond amongst themselves thereby strengthening the group cohesion." Yet, in the broader definition presented by Wepener and Cilliers above one also hears about the dangers of bonding in that it can become "a basis for the pursuit of narrow and even sectarian interests." This is in

27 See Smith-Christopher (2002:137-162) and Gerstenberger (2005:378-382).

28 See the more extensive argument in Meyer (2011:142-158), especially the critical engagements with the contributions of Jacob Milgrom and Mary Douglas.

29 To my mind the best explanation offered for the origins of the eating laws was provided by Walter J. Houston (1993). His contribution is summed up as follows by Nihan (2007:330): "the dietary rules in Lev 11 and Deut 14 largely appear to correspond to the accepted dietary and sacrificial customs in a dominantly pastoralist economy such as that of pre-exilic Israel."

30 As mentioned above, Milgrom would not read Leviticus as a post-exilic text, but regards the whole book (both $\mathrm{P}$ and H) as pre-exilic. See especially Milgrom (1999).

31 I am not sure that Bell would approve of the fact that I basically describe all eating by Jews in the Second Temple Period as an example of "ritualisation". In her (Bell 1992:90-91) own discussion of "ritualisation of the meal" she argues that one needs a "different set of strategies to differentiate it from conventional eating". Leviticus 11 is not about a feast which has a clear ritualised character, but it is about the fact that eating is not an innocent act, but an act whereby Second Temple Yehud differentiated themselves from other peoples in the Persian Empire. Bell (1992:90) often uses the concept of differentiation, but then applies it to an act which by means of ritualisation differentiates itself from a normal act. As she puts it (Bell 1992:90), "ritualisation is the production of this differentiation." I am thus applying this act of differentiation not to the ritual act itself but to a group of people in the Persian Period. 
NGTT Deel 54, Nommers 3 \& 4, September en Desember 2013

line with traditional portrayals of the world view of $\mathrm{P}$ as indeed sectarian or exclusive, but it is usually understood within a Persian Period historical context where the survivors of the exile attempted to keep on surviving and maintain their identity in the midst of the broader Persian Empire..$^{32}$ It was with this in mind that I initially mentioned above that when I attempted to relate "social capital" to the book of Leviticus, my first response was to look for bonding over against something like bridging. Wepener (2010:1) defines bridging as "the ways in which groups or individuals can form relationships with people belonging to groups other than their own", while linking is defined as referring "to the ways in which individuals and groups link with people or groups that are on a different societal level than themselves". Thus Mbaya (2011), in his article on the Corinthian Church where he describes the isitshisa sacrifice, concludes:

"In other words, worship and meals enhance bonding social capital as the isitshisa [burning of the heifer] draws people into fellowship. Because generosity is extended to the blind and the needy, this dimension of networking is an example of linking capital."

The isitshisa is a sacrifice reminiscent of the purification offering found in Leviticus 4-5 and is explicitly linked to the red cow ritual in Numbers $19 .{ }^{33}$ The Corinthians perform this sacrifice once a year and on the day after the isitshisa blind people are brought by bus to the church and are then presented with "presents of money, clothes and food parcels" (Mbaya 2011:6). For Mbaya (2011:7) this amounts to "linking capital" ${ }^{34}$ whereby blind people are integrated into society and this is the direct result of the ritual of the sacrifice. ${ }^{35}$

There might be some bridging going on in the book of Leviticus. It was already mentioned above that one community-related concern which enters the text of Leviticus in the second half is the issue of strangers (gērim), whom we find first in Leviticus 16, but who then frequently feature in $\mathrm{H}^{3}{ }^{36}$ Albertz (2011:59) expresses the following view of the identity of the strangers in the Holiness Code:

"In my view, the gērim here are all those foreigners, who inhabited - shoulder to shoulder with the Judeans - the Persian province of Jehud in the first part of the 5th century, whose multi-ethnic character is known from other sources."

The society of the post-exilic period was thus what we would call multicultural and the

32 See Smith-Christopher (2002:160-162).

33 For a more detailed description of this ritual compared to Numbers 19, see Wepener and Meyer (2012:298-318). Or see Mbaya's (2011: 3-5) description.

34 I must say that I find the differences between bonding and linking rather vague, but that probably has to do with the fact that I am not a practical theologian. From the overview provided by Brouwer (2009:7274) it also seems that Putman originally spoke only of bonding and bridging and that the third category of linking was later added by John Field. My argument above tends to treat bridging and linking as more or less synonymous. See also Bayat (2005:4-5) who defines the bridging network as being "characterized by generalised trust and charitable volunteering" whereas linking are about the "links between the political elite and the general public or between individuals from different social classes." In terms of the definitions provided by Bayat, what Mbaya is describing above, is more a case of bridging than linking. Yet it should be clear how both are different from bonding. In the rest of the article I will simply talk of bridging.

35 His argument is slightly more complex than implied above. At some stage one of the church leaders is asked "What relevance has the isitshisa to the donations to the blind?" (Mbaya 2011:7) His answer indicates that sacrificing the heifer reminds the congregation members of sacrificing themselves for the sake of others.

36 Leviticus 16:29; 17:8, 10, 12, 13, 15; 18:26; 19:10, 33, 34; 20:2; 22:18; 23:22; 24:16, 22; 25:23, 35, 47. 
NGTT: Oopbron - http://ngtt.journals.ac.za

Holiness Code attempts to address this historical reality. In Leviticus 16:29 the strangers are ordered not to work, just as they are ordered in Leviticus 17:10,12 not to consume blood, or as they are forbidden in 18:26 to transgress the sexual taboos described in Leviticus 18. Milgrom (2000:1499) has described these commandments as prohibitive, which means that their violation could "lead to the pollution of God's sanctuary and land, which, in turn, results in God's alienation and Israel's exile." Or, as Albertz (2011:60) puts it, the purpose of these laws is "to avert a new catastrophe from the Judean province." The logic of these laws was thus to protect the addressees from losing the land. The strangers could also defile the land, which would result in its loss.

Yet the strangers themselves are also sometimes protected, as we have seen in Leviticus 19. In verse 10 some of the harvest is left for the poor and the strangers, and in verses 33 and 34 of the same chapter the addressees are commanded not to oppress strangers, but rather to treat them like fellow citizens. The addressees are then reminded that they themselves were previously strangers in Egypt. Is this command an example of bridging? ${ }^{37}$ The addressees are invited to sympathise with these "other people" and to treat them as they would themselves. This sensitivity in the second half of Leviticus is closely related to the "ethical turn" described above which saw Leviticus move away from a narrow cultic focus to a more community-based ethics. But could one call this a kind of bridging, where the Judean society of the post-exilic period attempted to "form relationships with people belonging to groups other than their own", as Wepener (2010:1) has put it? A very careful "yes" might be an appropriate response now.

Although Albertz (2011:61-67) thinks that the "Holiness legislators were not mainly interested in converting the resident aliens to Yahwism," he still argues that, when one looks at how the treatment of the strangers developed from the Covenant Code, Deuteronomy, the Holiness Code and then in the "Late Priestly layers",38 this development might form the basis of the much later concept of proselytes. One could say that Albertz thus detects a fairly long process of opening up towards strangers, which is probably a kind of bridging. Still, this does not say anything about the possible relation between rituals and social capital, as some practical theologians (such as Mbaya above) ${ }^{39}$ would have it. The development in attitudes towards the strangers in the Holiness Code was mostly the result of "a new social-economic and historical situation, which was largely unforeseen by the earlier legal collections." (Nihan 2011:131) It is not as if the rituals in the first half of the book created a society which was eventually slightly more open towards strangers. It was probably more a case of adapting to new historical realities.

The lingering question at the end of this essay is whether the concept of "social capital" as used by practical theologians has helped us to gain a better understanding of the book of Leviticus or not?

37 Or, even linking? Apart from the fact that I find the two concepts rather foggy, it would also depend on how one defines the strangers. Do they belong to a lower social order as Leviticus 1933-34 and 23:22 would have us believe, or are they as rich as, or even more rich than the addressees themselves? The end of chapter 25 describes some strangers as very rich. Nihan (2011:131) argues that they might have been part of the Persian elite.

38 By "Late Priestly Layers", Albertz (2011: 63-65) means the priestly texts in the book of Numbers, which are even later than H. In these texts "the path was paved in the direction of proselytes." Albertz 2011:65)

39 I am not saying that I do not find Mbaya's argument in relation to his discussed case study convincing. In terms of the Corinthians and their sacrifices, he might be spot on. I am saying that that does not really help us to explain what is happening in the book of Leviticus. 


\section{CONCLUSION}

The answer to this question is probably "uncertain". If what I have identified in the light of Leviticus 11 and the appearance of the stranger in the second half of Leviticus could indeed be described as bonding and bridging, it would only mean that we have used new name tags for phenomena already identified and described by many scholars working on Leviticus. Still, engaging with these concepts might sensitise Biblical critics to look at old texts with new eyes.

I have also shown above that a study of the book of Leviticus can only partially contribute to the broader debate (in practical theology) about the effect of ritual/religion on the formation of social capital. There is a clear link between rituals and bonding which is at least one component of social capital, although this is often regarded as dangerous in itself, when the other components are absent. I tried to show this by means of Leviticus 11. Even if a case might be made for bridging in the second half of Leviticus when the strangers enter the text, this has little to do with the rituals in the first half of Leviticus. The way in which Biblical critics usually explain the "turn to the other" in the second half of the book of Leviticus has to do with arguments about dating and historical contexts, and most are convinced that $\mathrm{H}$ is later than $\mathrm{P}$ and is thus not strictly speaking representative of the same society. The ethical turn in Leviticus is not a logical development from the ritual-dominated first half. The ethical turn is a response to a different historical context and a response to what we could call an inner-Biblical ${ }^{40}$ discussion taking place between different legal codes in the Pentateuch (as Otto would have it), but probably also between traditions in the Pentateuch and traditions in Prophetic texts (as Knohl would have it).

There is thus social capital in Leviticus, both bonding and maybe even bridging, but only the former could be regarded as a result of rituals. The change to bridging was brought about by a changed historical context when the people of Yehud found themselves in a province of the much bigger Persian Empire. They now had to share this province with people who were different from them. In this light one wonders about the role of rituals and religion in changing societies. Priestly theology did not bring about change, but it did respond to a changing historical context. Initially in the time period shortly after the exile Priestly theology and its associated rituals helped the exiles to survive and maintain their identity which could be a case of bonding. The first half of Leviticus witnesses to that. Later the authors of $\mathrm{H}$ responded to a different historical context and created a different kind of social capital namely bridging. Priestly theology and associated rituals did not bring about this change, but it managed the change. Maybe this is what practical theologians should focus on in modern day contexts, namely how is social capital created in response to a changing world? What role does religion and its associated rituals play in managing the survival and adaptation of religious groups in a changing world?

\section{BIBLIOGRAPHY}

Albertz, R 2011. “From Aliens to Proselytes: Non-Priestly and Priestly Legislation Concerning Strangers." in, Achenbach, R; Albertz, R and Wöhrle, J (eds.) The Foreigner and the Law: Perspectives from the Hebrew Bible and the Ancient Near East. Wiesbaden: Harrassowitz, 53-69. Balentine, SE 1999. The Torah's Vision of Worship. Minneapolis: Fortress Press. Bayat, A 2005. "Defining Social Capital: A brief overview of the key aspects and debates."

40 See the title of Otto (1999). 
NGTT: Oopbron - http://ngtt.journals.ac.za

Discussion paper presented at a Workshop on 'Social Capital'. University of the Western Cape, February 17.

Bell, C 1992. Ritual Theory, Ritual Practice. Oxford: Oxford University Press.

Bergen, WJ 2005. Reading Ritual: Leviticus in Postmodern Culture. London: T \& T Clark.

Bibb, BB 2009. Ritual Words and Narrative Worlds in the Book of Leviticus. London: T \& T Clark.

Brouwer, R 2009. Geloven in gemeenschap: Het verhaal van een protestantse geloofsgemeensc-

hap. Kampen: Kok.

Carr, DM 2011. The Formation of the Hebrew Bible: A New Reconstruction. Oxford: Oxford University Press.

Collins, JJ 2004. Introduction to the Hebrew Bible. Minneapolis: Augsburg Fortress.

Gerstenberger, ES 2005. Israel in der Perserzeit: 5. und 4. Jahrhundert v. Chr. Stuttgart: Kohlhammer.

Houston, WJ 1993. Purity and Monotheism: Clean and Unclean Animals in Biblical Law. Sheffield: Sheffield Academic Press.

Kaiser, WC 1994. "The Book of Leviticus." in, Keck, L (ed.) The New Interpreter's Bible. Volume 1. Nashville: Abingdon Press, 985-1191.

Klostermann, A 1893. Der Pentateuch: Beiträge zu seinem Verständnis und seiner Entstehungsgeschichte. Leipzig: Deichert.

Knohl, I 1995. The Sanctuary of Silence. The Priestly Torah and the Holiness School. Minneapolis: Fortress Press.

Mbaya, $\mathrm{H}$ 2011. "The socio-practical dimension of isitshisa [burning of the heifer] in the Corinthian Church of South Africa." HTS Teologiese Studies/Theological Studies 67:2, 1-8.

Meyer, EE 2010. “Dating the Priestly text in the pre-exilic period: Some remarks about anachronistic slips and other obstacles," Verbum et Ecclesia 31:1, 1-6.

Meyer, EE 2011. "Respect of Animal Life in Leviticus. How Green Were the Priestly Authors?" Old Testament Essays 24:1, 142-158.

Meyer, EE 2012. "Leviticus 17 as a bridge between P and H, with a twist of D?" Journal for Semitics 21:1, 106-124.

Meyer, EE 2013. "From cult to community: The two halves of Leviticus." Verbum et Ecclesia 34:2, 1-7.

Milgrom, J 1999. "The Antiquity of the Priestly Source: A Reply to Joseph Blenkinsopp."

Zeitschrift für die Alttestamentlichen Wissenschaft 111:10-22.

Milgrom, J 2000. Leviticus 17-22: A New Translation with Introduction and Commentary. New York: Yale University Press.

Milgrom, J 2004. Leviticus. Minneapolis: Fortress Press.

Nihan, C 2007. From Priestly Torah to Pentateuch. Tübingen: Mohr Siebeck.

Nihan, C 2011. "Resident Aliens and Natives in the Holiness Legislation." in, Achenbach, R; Albertz, R and Wöhrle, J (eds.) The Foreigner and the Law: Perspectives from the Hebrew Bible and the Ancient Near East. Wiesbaden: Harrassowitz, 111-134.

Olyan, SM 2012. (ed) Social Theory and the Study of Israelite Religion: Essays in Retrospect and Prospect. Atlanta: Society of Biblical Literature.

Otto, E 1999. “Innerbiblische Exegese im Heiligkeitsgesetz Levitikus 17-26," in H-J Fabry and H-W Jüngling (eds.) Levitikus als Buch. Berlin: Philo, 125-196.

Otto, E 2009. "The Holiness Code in Diachrony and Synchrony in the Legal Hermeneutics of the Pentateuch," in S Shectman and JS Baden (eds.) The Strata of the Priestly Writings. Contemporary Debate and Future Directions. Zürich: TVZ, 135-156.

Smith-Christopher, DL 2002. A Biblical Theology of Exile. Minneapolis: Augsburg Fortress. Stackert, J 2009. "The Holiness Legislation and Its Pentateuchal Sources: Revision, Supple- 
NGTT Deel 54, Nommers 3 \& 4, September en Desember 2013

mentation, and Replacement," in S Shectman and JS Baden (eds.) The Strata of the Priestly Writings. Contemporary Debate and Future Directions. Zürich: TVZ, 186-201.

Trevaskis, LM 2011. Holiness, Ethics and Ritual in Leviticus. Sheffield: Phoenix Press.

Wepener, C 2010. "Snert: Ritual-liturgical measurements and recipes for social capital," Verbum et Ecclesia 31:1, 1-7.

Wepener, C and Barnard, M 2010. “Entering the Field: Initiating liturgical research in an African Independent Church (AIC)," Acta Theologica 30:2, 192-210.

Wepener, C and Cilliers, J 2010. "Ritual and the Generation of Social Capital in Contexts of Poverty," in I Swart et al (eds.), Religion and Social Development in Post-Apartheid South Africa. Stellenbosch: SUN Press, 417-429.

Wepener, C and Meyer EE 2012. "Ritual Burning and Slaughtering in an AIC: Perspectives from Liturgical Studies and Old Testament Criticism," Religion \& Theology 19, 298-318.

Wright, DP 1999. "Holiness in Leviticus and Beyond. Differing Perspectives," Interpretation 53, 351-364.

Wright, DP 2001. Ritual in Narrative: The Dynamics of Feasting, Mourning, and Retaliation Rites in the Ugaritic Tale of Aqhat. Winona Lake: Eisenbrauns.

Wright, DP 2012. "Ritual Theory, Ritual Texts, and the Priestly-Holiness Writings of the Pentateuch," in Olyan, SM (ed) Social Theory and the Study of Israelite Religion: Essays in Retrospect and Prospect. Atlanta: Society of Biblical Literature, 195-216.

Zenger, E 2008. Einleitung in das Alte Testament. 7. Auflage. Stuttgart: Kohlhammer.

\section{KEY WORDS}

Social capital

Leviticus

Holiness Code

\section{TREFWOORDE}

Sosiale kapitaal

Levitikus

Heiligheidskodeks

Contact Details

Meyer, Esias E

Department of Old Testament Studies,

University of Pretoria

South Africa

sias.meyer@up.ac.za

0124202719

0836622697 